Article

\title{
Applicability of Benthic Diatom Indices Combined with Water Quality Valuation for Dish Lake from Nanjishan Nature Reserve, Lake Poyang
}

\author{
Junfei Yang ${ }^{1}$, Yong $\mathrm{Ji}^{1, * \mathbb{D}}$, Ruyu Yan ${ }^{1}$, Xingchen Liu ${ }^{1}$, Jie Zhang ${ }^{1}$, Naichen $\mathrm{Wu}^{2}$ and Kai Wang ${ }^{1}$ \\ 1 College of Water Conservancy and Ecological Engineering, Nanchang Institute of Technology, \\ No. 289 Tianxiang Dadao, Nanchang Institute of Technology, High-Tech Zone, Nanchang 330099, China; \\ yangjunfei2020@163.com (J.Y.); yanruyuu96@163.com (R.Y.); liuxingchenn96@163.com (X.L.); \\ Zhangjie@nit.edu.cn (J.Z.); wangkai8133@163.com (K.W.) \\ 2 Aarhus Institute of Advanced Studies, Aarhus University, Høegh-Guldbergs Gade 6B, \\ 8000 Aarhus C, Denmark; wnc8133vip@163.com \\ * Correspondence: Jiyong@nit.edu.cn; Tel.: +86-18379483027 or +86-13507000704
}

Received: 26 August 2020; Accepted: 24 September 2020; Published: 30 September 2020

\begin{abstract}
Benthic diatom indices developed in the Europe Union have been widely accepted as indicators of the trophic state and water quality in freshwater ecosystems. In China, most of the benthic diatom-based indices have not been widely tested or evaluated before. For this purpose, the water quality parameters and benthic diatoms community structures at 20 sample sites in the dish lake of Nanjishan Nature Reserve in Poyang Lake were investigated in this study and 18 widely-applied diatom indices were established. The statistical results indicated that most water quality parameters including Total Nitrogen (TN), Total Phosphorus (TP), ammonia nitrogen $\left(\mathrm{NH}_{4}{ }^{+}\right)$, Chemical Oxygen Demand (COD) and Chlorophyll (Chl) were highly correlated with each other at a confidence level of 0.05 . Water quality sampling sites from 8 lakes could be classified into 4 groups based on the integrated comprehensive scores using principal components analysis (PCA). Monitoring sites could also be divided into 4 groups based on clustering analysis with hierarchical methods for diatom dominant species in 20 sampling sites. According to the status of water ecological health recognition and box plot analysis in different water quality groups and diatom dominant species groups, only 3 diatom indices including the Biological Diatom Index (IBD), Specific Pollution Sensitivity Index (IPS) and Louis Leclercq Diatom Index (IDSE) demonstrated good evaluation suitability and good correlation within different water quality grades at the final stage. The above results revealed that IBD, IPS and IDSE were the most suitable diatom indices for the water quality evaluation of the dish lake in the Nanjishan Nature Reserve, Lake Poyang.
\end{abstract}

Keywords: diatom index; dish lake; water quality evaluation; benthic diatoms; Lake Poyang

\section{Introduction}

Various anthropic activities have put riverine ecosystem under continuous threat worldwide leading to freshwater ecosystems degradation, water quality deterioration, eutrophication and loss of biodiversity [1,2]. Meanwhile, growing concerns about declining water quality and ecosystem health have also attracted continuous attention for the integrative assessment of freshwater systems $[3,4]$. Monitoring technologies, such as physical monitoring and chemical monitoring relying on water quality and structural analysis of the habitat, play a vital role in aquatic ecosystem protection $[1,5,6]$, which could effectively determine the types and quantities of various contamination in water bodies and function as one of the important parts of water quality monitoring [7]. In contrast, biological monitoring using the various reactions of individuals or groups of organisms to pollutants could 
directly characterize the quality of the environment and the degree of pollution [8]. Since the 1970s, fishes, macro-invertebrates and diatoms had been widely used for freshwater ecological environment monitoring by the Environmental Protection Agency (EPA) of the US and Water Framework Directive (WFD) of the EU [1,9].

As primary producers and sensitive organisms, short-term environmental fluctuations in ecosystems could be found in diatom communities at the sampling site because they have a short life cycle as unicellular microalgae $[10,11]$. Lots of studies revealed that diatom communities could effectively respond in different ways for different types of contamination, such as nutrients, organic pollutants and heavy metal pollutants, which eventually made them effective environmental indicators of water quality [12,13]. Among them, benthic diatoms were widely accepted as representative species because they are widely available and easily accessible $[14,15]$. Furthermore, benthic diatoms are usually fixed to survive in a specific environment, tolerant to environmental changes and do not migrate due to environmental changes [16]. Studies have also shown that attached diatoms have a good indication of water quality eutrophication and human disturbance activities $[2,17,18]$, which has been accepted as a biological indicator for river ecological health monitoring [19-21].

Based on statistical methods, various diatom indices, by summarizing and quantifying information provided by the diatom assemblages, have been gradually established and implemented for water quality and ecological system status assessment around the world [13,22]. In the European countries, different diatom indices have extensively been used for the assessment of water quality particularly with reference to eutrophication and organic pollution [1,23-25], and they were also proved to be one of the most effective tools for evaluating the health of the ecosystem [18,26]. Among them, the Trophic Diatom Index (TDI) combined by a weighting average equation was developed to show the impact of nutrients and confirmed for aquatic monitoring streams in the Swedish national system $[4,27]$. The Specific Pollution Sensitivity Index (IPS) was developed to show the impact of nutrients and organic pollution in streams [28].

However, studies revealed that some diatom indices developed in certain parts of Europe were not sensitive enough when they were used in other areas of the same continent [29,30]. Many researchers also believed that the diatom indices had the best application area where the combination of different diatoms could respond to the unique environment of each region [31,32]. Compared with the first proposal of the TDI by Kelly and Whitton [33], researchers proposed a second edition based on the applicability of diatom species to different water quality [34]. All in all, researchers indicated that different diatom indices had their own suitable conditions for assessing water quality in subtropical or tropical zones [7,12].

Nanjishan Nature Reserve is part of Lake Poyang in Jiangxi Province and consists of countless small dish-shaped lakes that connect together in the flood season, which has formed a unique wetland system and maintains a rich biodiversity [20]. Water pollution and hydrological rhythms changes caused by high-intensity human activities could be catastrophic for the biodiversity [25]. In order to evaluate the degree of eutrophication and select the appropriate diatom indices, several small dish-shaped lakes in the Nanjishan Nature Reserve based on early stage investigation were chosen as the research area. After that, indices of 18 different benthic diatom species were evaluated using the Water Framework Directive step by step, as well as the assessment of water quality variables. The method that was applied during this process has been widely adopted for the evaluation of diatom index suitability before their entry into special regions $[23,26]$.

\section{Materials and Methods}

\subsection{Study Area}

As illustrated in Figure 1, the Nanjishan Nature Reserve, consisting of Nanshan island and Jishan island, is located at the southern part from the main lake area of Poyang Lake in Jiangxi Province, which ranges from $28^{\circ} 54^{\prime} 30^{\prime \prime}-28^{\circ} 58^{\prime} 2^{\prime \prime} \mathrm{N}$ to $116^{\circ} 15^{\prime} 38^{\prime \prime}-116^{\circ} 20^{\prime} 32^{\prime \prime}$ E and covers an area 
of approximately $33,300 \mathrm{hm}^{2}$. The lake area of Poyang Lake fluctuates from $4000 \mathrm{~km}^{2}$ to $3000 \mathrm{~km}^{2}$ between the wet and dry seasons, while the water level decreases seasonally from a maximum of $19.4 \mathrm{~m}$ in August to $7.9 \mathrm{~m}$ in January [35]. For those major seasonal water level fluctuations, the lake exhibits the characteristics of a river during the dry season and those of a lake during the wet season [36]. The nature reserve was gradually formed by settlement of huge amounts of silt carried by hydrodynamic transmission of the three major tributaries of the Ganjiang River, including the Middle Branch, the North Branch and the South Branch from upstream mountains, which made the Nanjishan Nature Reserve the most fertile land and maintains the richest biodiversity in Poyang Lake Basin. Due to the flooding and ecological protection requirements, the Nanjishan Nature Reserve is well protected by extremely low population density and fewer human activities now [20].

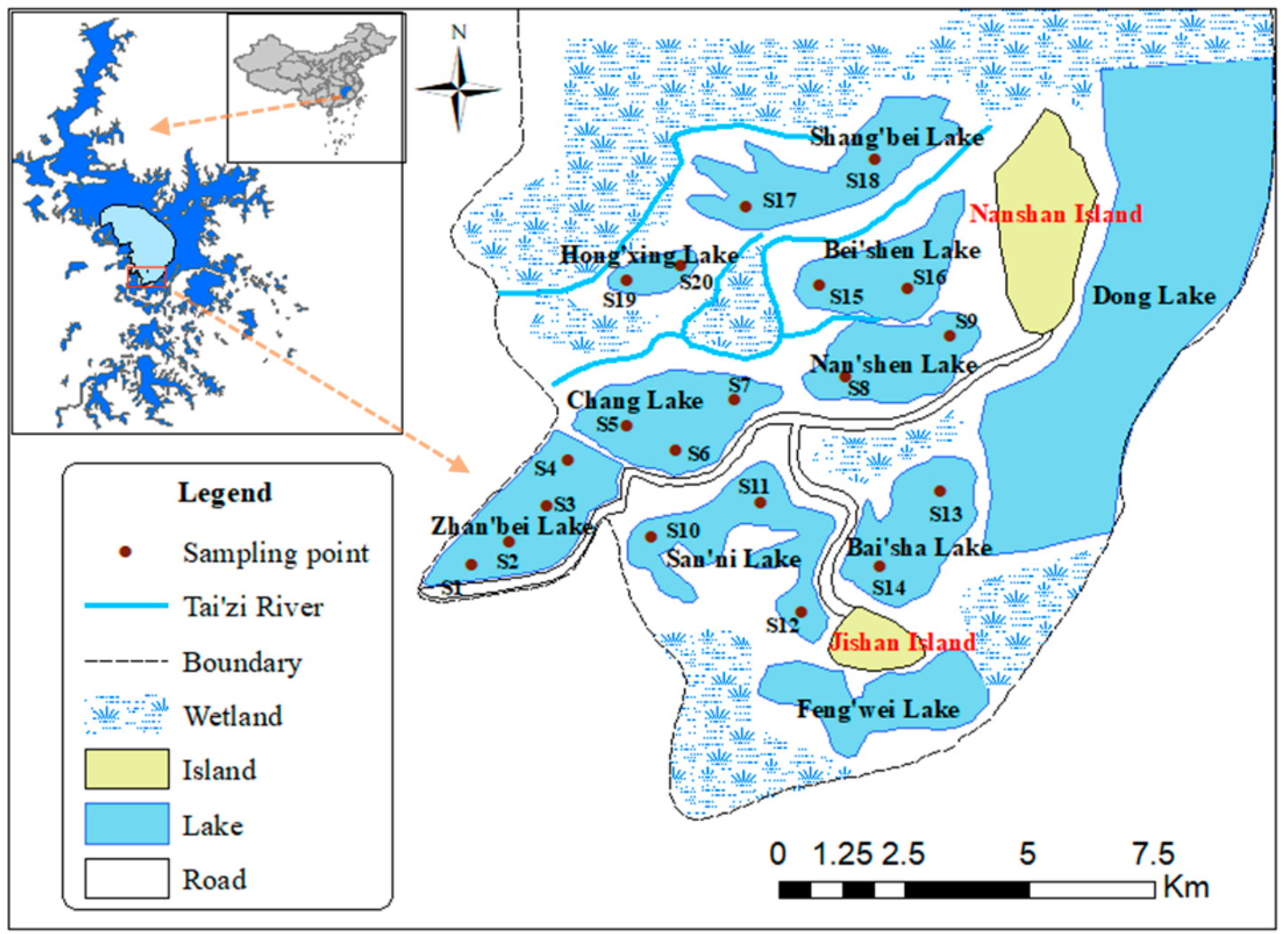

Figure 1. Geological location and information of the sampling sites in the Nanjishan Nature Reserve of Poyang Lake, China.

\subsection{Sampling Sites}

Based on spot-field investigation and consultation from local residents, eight dish-shaped lakes distributed around Nanshan and Jishan islands from the Nanjishan Nature Reserve, which represent three types of lakes with different environmental impacts, were chosen as the sampling sites area, including Zhan'bei, Chang, Nan'shen and San'ni Lake and so on. The first type of lake refers to those which were used for aquaculture since the 1980s with higher-level contamination of Total Nitrogen (TN), Total Phosphorus (TP), Total Organic Carbon (TOC) and heavy metal contents [37]. The second type of lake refers mainly to those where boat transport was often confirmed by the lake. The last type refers to those that are less affected due to being far from the residential area. In this research, four sampling sites named S1, S2, S3 and S4 were set up in the Zhan'bei Lake, three sampling sites named S5, S6, S7 and S10, S11, S12 were set up in the Chang and San'ni Lake. Meanwhile, two sampling sites were set up in Nan'shen, Bai'sha, Shang'bei, Bei'shen and Hong'xing Lake, respectively. The location, characteristics and detailed information of each sampling site are listed in Figure 1. 


\subsection{Water Sampling}

At each site, $1 \mathrm{~L}$ of water was collected under $0.5 \mathrm{~m}$ water depth using a water sampler (HJ09-1000 Beixinke China) in March 2019 and loaded in rinsed (three times at each site) plastic containers following guidelines for the collection of water samples [38]. After marking with tags, those water samples were then transported by car refrigerator (T12 Indel Italy) to the lab where the water would be processed within $24 \mathrm{~h}$. The geographic coordinate information of the sampling sites was also recorded using a handheld GPS (eTrex-30X Garmi China). Physicochemical parameters including water temperature, $\mathrm{pH}$ and Dissolved Oxygen (DO) were measured on sites with a multifunctional on-site water quality analyzer (JPB-607A REX China). Standard methods were also used for other water quality parameters, including Total Nitrogen (TN), Total Phosphorus (TP), ammonia nitrogen $\left(\mathrm{NH}_{4}{ }^{+}\right)$, Chlorophyll (Chl), Chemical Oxygen Demand (COD) and Total Suspended Solids (TSS) [38].

\subsection{Diatom Sampling}

A minimum of three rock, epiphytic plant or dead branch samples at a water depth from 100 to $300 \mathrm{~mm}$ from each site were randomly chosen from each dish lake [39,40]. The upper side of the rocks, epiphytic plants and dead branches were carefully scraped with a new toothbrush at each site to avoid inter-site contamination and all of the rocks, epiphytic plants and dead branches were rinsed in a specimen jar using pure water. After that, those samples were then fixed by adding 3-5\% formaldehyde solution in a $50 \mathrm{~mL}$ labeled specimen container, which were next stored and transported in a car refrigerator (T12 Indel Italy) to the laboratory where samples were refrigerated at $4{ }^{\circ} \mathrm{C}$ until further processing.

\subsection{Diatom Identification}

Diatoms were processed in the laboratory following the method of EN13946 and EN14407 [13]. Two digestion processes were performed in a water bath at $80{ }^{\circ} \mathrm{C}$ until the end of the chemical reaction. First, $10 \%$ dilute hydrochloric acid (HCL) was used to remove carbonates in the samples. After that, $20 \%$ hydrogen peroxide $\left(\mathrm{H}_{2} \mathrm{O}_{2}\right)$ was then processed to remove any remaining organic matter in the samples. Finally, the samples were operated in a centrifuge at $3000 \mathrm{rpm}$ for $10 \mathrm{~min}$ to allow diatoms to settle down, and the diatoms were cleaned and permanently slide mounted. Species were finally identified in the diatoms using an Olympus compound microscope (CX31 OLYMPUS Philippines) at $1000 \times$ magnification.

\subsection{Diatom Indices Calculation}

The diatom species quantities were used to calculate 18 diatom indices recommended by the European Union, which was performed using OMNIDIA 5 [7]. The following are abbreviations of 18 diatom indices: (Diatom Eutrophication Pollution Index, EPI-D), (Specific Pollution Sensitivity Index, IPS), (Rott Trophic Index, ROTTTroph), (Descy Index, DES), (DI-CH Index, DI-CH), (Generic Diatom Index, IDG), (Sládeček Index, SLA), (Percentage pollution tolerant valves, \%PT), (Artois-Picardy Diatom Index, IDAP), (Schiefele-Schreiner Diatom Index, SHE), (Watanabe Index, WAT), (Lobo Index, LOBO), (Biological Diatom Index, IBD), (Pampean Diatom Index, IDP), (Louis Leclercq Diatom Index, IDSE), (Rott Sap. Index, ROTTsap), (European Economic Community Index, CEE).

Due to different calculation methods and different diatoms being adopted, each index represents a different environmental indicator and has been evaluated for ecological relevance from compiled literature information [22,34]. The McNaughton dominance index $(\mathrm{Y})$ was used for dominant diatom species selection in the Nanjishan Nature Reserve, by which dominant species were confirmed from communities when their $Y$ value was more than 0.02 [41]. In this study, diatom species in different dish-shaped lakes with a value of $Y$ greater than 0.02 were identified as dominant species. 


\subsection{Statistical Analysis}

A Pearson correlation coefficient matrix was calculated to determine the relationship between environmental variables and diatom indices at $p<0.05$ and $p<0.01$ levels. Principal Components Analysis (PCA) was conducted to identify the major environmental variables that influenced the data set. Hierarchical clustering was used to classify water quality and to determine the dominant species of each group. Diatom index values were used to assess river health levels, following the standards of river health. To confirm the best suitable diatom indices for the Nanjishan Nature Reserve, box plots of the screened diatom indices were drawn step by step and fully compared with the environmental parameters with statistical methods. In this study, Excel 2016, SPSS 22, OMNIDIA 5.2, Canoco 5.0, Origin 2016 and ArcGIS10.2 were used to process the experimental data and draw graphics.

\section{Results}

\subsection{Classification of Water Quality}

The physical and chemical parameters of the water quality at 20 sampling sites of eight dish-shaped lakes are presented in Table 1. In general, water quality variables demonstrated wide variation, such as TN ranging from 0.15 to $0.57 \mathrm{mg} / \mathrm{L}$, TP ranging from 0.01 to $0.07 \mathrm{mg} / \mathrm{L}, \mathrm{Chl}$ ranging from 4380 to 9350 $\mathrm{ug} / \mathrm{L}, \mathrm{COD}$ ranging from 7.2 to $28.3 \mathrm{mg} / \mathrm{L}$ and $\mathrm{NH}_{4}{ }^{+}$ranging from 0.15 to $0.39 \mathrm{mg} / \mathrm{L}$. Comparing with standard values recommended by national mandatory standards (Wei et al., 2002), low values of TN and TP values were observed at S18, S19 and S20 in Hong'xing and Shang'bei Lake, and lower values were also recorded for TSS with a minimum value at $\mathrm{S} 19$ of $8.7 \mathrm{mg} / \mathrm{L}$. Meanwhile, the highest values for TN, TP and $\mathrm{NH}_{4}{ }^{+}$were all recorded in Zhan'bei, San'ni and Bai'sha Lake. Values of TN, TP, $\mathrm{NH}_{4}{ }^{+}$, Chl and COD in Nan'shen, Shang'bei, Bei'shen and Chang Lake were recorded at the median level.

Principal component analysis based on the water quality data was used to find the most critical factor and to classify different monitoring sites based on the integrated scores as indicated in Table 1 . The first principal component (PC1) had an eigenvalue of 4.197 which accounted for $69.949 \%$ of the variances, while the second principal component (PC2) with an eigenvalue value of 0.858 explained $14.298 \%$ of the total variation. The cumulative contribution of the PC1 and PC 2 was $84.247 \%$, which could well reflect the information provided by the original variables. TN, TP and Chl showed the highest loading values respectively and contributed the most to the variances of the PC1, which could represent a signifying varying degree of eutrophic pollution, indicating that TN, TP and Chl had a great impact on the classification of water quality. $\mathrm{NH}_{4}{ }^{+}$had the highest loading values on the $\mathrm{PC} 2$, which could be used to reflect conventional water quality indicators.

As presented in Table 1, 20 water quality sampling sites from 8 lakes could be classified into 4 groups based on the integrated comprehensive scores of the principal components PC1 and PC2, which divided the water quality into four groups (A1, A2, A3 and A4) with a decreasing trend. The lowest values of TN $(0.15 \mathrm{mg} / \mathrm{L})$ and TP $(0.01 \mathrm{mg} / \mathrm{L})$ were observed at the sites in group A1, where the COD $(7.2 \mathrm{mg} / \mathrm{L})$ value was also the lowest. The highest values of TN $(0.57 \mathrm{mg} / \mathrm{L})$ and TP $(0.07 \mathrm{mg} / \mathrm{L})$ were observed at the sites in group A4 with the highest values of $\mathrm{NH}_{4}{ }^{+}(0.39 \mathrm{mg} / \mathrm{L})$, COD $(28.3 \mathrm{mg} / \mathrm{L})$ and Chl $(9.35 \mathrm{mg} / \mathrm{L})$. 
Table 1. Water quality parameters mean values and principal component scores for each sampling site.

\begin{tabular}{|c|c|c|c|c|c|c|c|c|c|c|c|}
\hline Group & Lake & Sites & TN (mg/L) & TP (mg/L) & COD $(\mathrm{mg} / \mathrm{L})$ & TSS (mg/L) & Chl (ug/L) & $\mathrm{NH}_{4}{ }^{+}(\mathrm{mg} / \mathrm{L})$ & PC1 & PC2 & $\mathbf{Y}$ \\
\hline \multirow{4}{*}{ A1 } & \multirow{2}{*}{ Shang'bei lake } & S17 & 0.27 & 0.03 & 11 & 12.7 & 4230 & 0.17 & -1.823 & -0.148 & -1.667 \\
\hline & & S18 & 0.2 & 0.03 & 7.2 & 10.8 & 4800 & 0.15 & -1.662 & 0.2 & -1.302 \\
\hline & \multirow{2}{*}{ Hong'xing lake } & S19 & 0.15 & 0.01 & 8.6 & 8.7 & 4860 & 0.16 & -0.993 & -0.419 & -1.575 \\
\hline & & S20 & 0.23 & 0.02 & 10 & 10.1 & 4730 & 0.2 & -1.414 & -0.654 & -1.496 \\
\hline \multirow{4}{*}{$\mathrm{A} 2$} & \multirow{2}{*}{ Nan'shen lake } & S8 & 0.31 & 0.03 & 17 & 14.5 & 5100 & 0.26 & -1.418 & 0.047 & -1.249 \\
\hline & & S9 & 0.24 & 0.04 & 12 & 15 & 4380 & 0.24 & -0.545 & -0.762 & -0.718 \\
\hline & \multirow{2}{*}{ Bei'shen lake } & S15 & 0.21 & 0.02 & 12 & 15 & 5020 & 0.19 & -1.012 & -0.512 & -1.063 \\
\hline & & S16 & 0.23 & 0.03 & 15 & 16.5 & 4980 & 0.26 & -1.581 & 0.033 & -1.37 \\
\hline \multirow{3}{*}{$\mathrm{A} 3$} & \multirow{3}{*}{ Chang lake } & S5 & 0.34 & 0.04 & 16 & 14.5 & 5970 & 0.26 & -0.75 & 0.235 & -0.359 \\
\hline & & S6 & 0.35 & 0.05 & 13 & 17 & 5610 & 0.24 & -0.64 & -0.222 & -0.276 \\
\hline & & S7 & 0.35 & 0.05 & 14 & 18.5 & 5840 & 0.27 & -0.472 & 0.166 & -0.542 \\
\hline \multirow{10}{*}{ A4 } & \multirow{4}{*}{ Zhan'bei lake } & S1 & 0.57 & 0.06 & 21.2 & 20.2 & 8210 & 0.37 & 1.508 & 0.542 & 1.421 \\
\hline & & S2 & 0.53 & 0.07 & 17.9 & 25.7 & 7360 & 0.3 & 1.364 & 1.534 & 1.416 \\
\hline & & S3 & 0.48 & 0.06 & 19.8 & 18.3 & 8350 & 0.39 & 1.217 & 1.196 & 1.204 \\
\hline & & $\mathrm{S} 4$ & 0.42 & 0.05 & 15.7 & 19.7 & 9200 & 0.32 & 0.896 & 0.586 & 0.718 \\
\hline & \multirow{3}{*}{ San'ni lake } & S10 & 0.41 & 0.05 & 21 & 17.3 & 6980 & 0.36 & 0.726 & 0.869 & 0.831 \\
\hline & & S11 & 0.39 & 0.04 & 28.3 & 15.5 & 7680 & 0.26 & 0.575 & 0.922 & 0.887 \\
\hline & & $\mathrm{S} 12$ & 0.42 & 0.04 & 20.6 & 18.9 & 9350 & 0.38 & 1.063 & 1.323 & 1.293 \\
\hline & \multirow{3}{*}{ Bai'sha lake } & S13 & 0.5 & 0.04 & 20.1 & 18.5 & 8670 & 0.32 & 1.014 & 0.404 & 0.985 \\
\hline & & S14 & 0.52 & 0.05 & 22 & 17.9 & 6390 & 0.29 & 0.649 & 0.56 & 0.605 \\
\hline & & Reference & 0.2 & 0.01 & 15 & - & - & 0.15 & - & - & - \\
\hline
\end{tabular}




\subsection{Diatom Communities Structure}

Seventy-seven species of diatoms, belonging to 7 families and 34 genera, were identified in this research. Among them, Melosira varians, Gomphonema gracile and Pinnularia viridis accounted for the top three species from the whole community of diatoms. Mcnaughton dominance index $\mathrm{Y}$ with a value of more than $2 \%$ of the total was used to determine the dominant species in the watershed. As presented in Table 2, the results revealed that Melosira varians indicated that eutrophication and organic pollution were widely recorded with the highest dominance index value of 0.137. Meanwhile, Gomphonema gracile was also frequently recorded with a higher dominance index value of 0.05 , which is usually used to indicate areas of multiple pollutants [42]. In addition, Synedra acus, Tabellaria flocculosa and Cyclotella meneghiniana indicated that mild or moderate pollution were also widely recorded [12].

Table 2. Dominant benthic diatom species with a value of $Y$ greater than 0.02 in Nanjishan Reserve.

\begin{tabular}{ccc}
\hline Latin Name & Abbreviation & Dominant Index \\
\hline Melosira varians & MVAR & 0.137 \\
Gomphonema gracile & GGRA & 0.051 \\
Pinnularia viridis & PVFM & 0.049 \\
Synedra acus & SACU & 0.043 \\
Cymbella tumida & CTUM & 0.043 \\
Synedra tabulata & STTG & 0.041 \\
Nitzschia gracilis & NIGF & 0.037 \\
Synedra ulna & SULN & 0.036 \\
Gomphonema olivaceum & GOLA & 0.036 \\
Fragilaria capucina & FCRP & 0.034 \\
Cyclotella meneghiniana & CMEN & 0.028 \\
Tabellaria flocculosa & TFAM & 0.027 \\
Eunotia lunaris & ELUN & 0.026 \\
Navicula amphibola & NAPH & 0.024 \\
Navicula capitata & NCAP & 0.024 \\
Eunotia arcus & EARC & 0.022 \\
Caloneis hyaline & CHYA & 0.022 \\
Cocconeis placentula & CPTG & 0.021 \\
Gomphonema constrictum & GCST & 0.020 \\
Neidium affine var & NAUC & 0.020 \\
Navicula veneta & NVEN & 0.020 \\
Cymbella cymbiformis & CCYM & 0.020 \\
Navicula trivialis & NTVT & 0.020 \\
\hline
\end{tabular}

Clustering analysis with hierarchical methods was applied for diatom dominant species in 20 sampling sites. After discriminant analysis was fully validated, 20 monitoring sites were divided into 4 groups (B1, B2, B3 and B4), which are presented in Figure 2, whereby B1 (S10, S11, S12, S13 and S14) was located in the south area, B2 (S1, S2, S3 and S4) was located in the west area, B3 (S5, S6, S7, S8 and S9) was located in the center area and B4 (S15, S16, S17, S18, S19 and S20) from in the north area. It is illustrated in the Figure 2 that Neidium affine var and Synedra acus were dominant species in B1, which indicates that it is a moderately polluted zone and has been known as eutrophic waters [22]. Tabellaria flocculosa, Navicula capitata, Cyclotella meneghiniana and Cocconeis placentula were dominant species in B2, meaning higher level of organic and eutrophic levels. B3 was dominated with Navicula veneta and Pinnularia viridis, indicating light organic pollution in these areas. B4 was less affected by pollution and was dominated by Gomphonema olivaceum and Cymbella cymbiformis. According to the indicator of the dominant species, the pollution levels of the 4 groups showed a downward trend: $\mathrm{B} 2>\mathrm{B} 1>\mathrm{B} 3>\mathrm{B} 4$. 


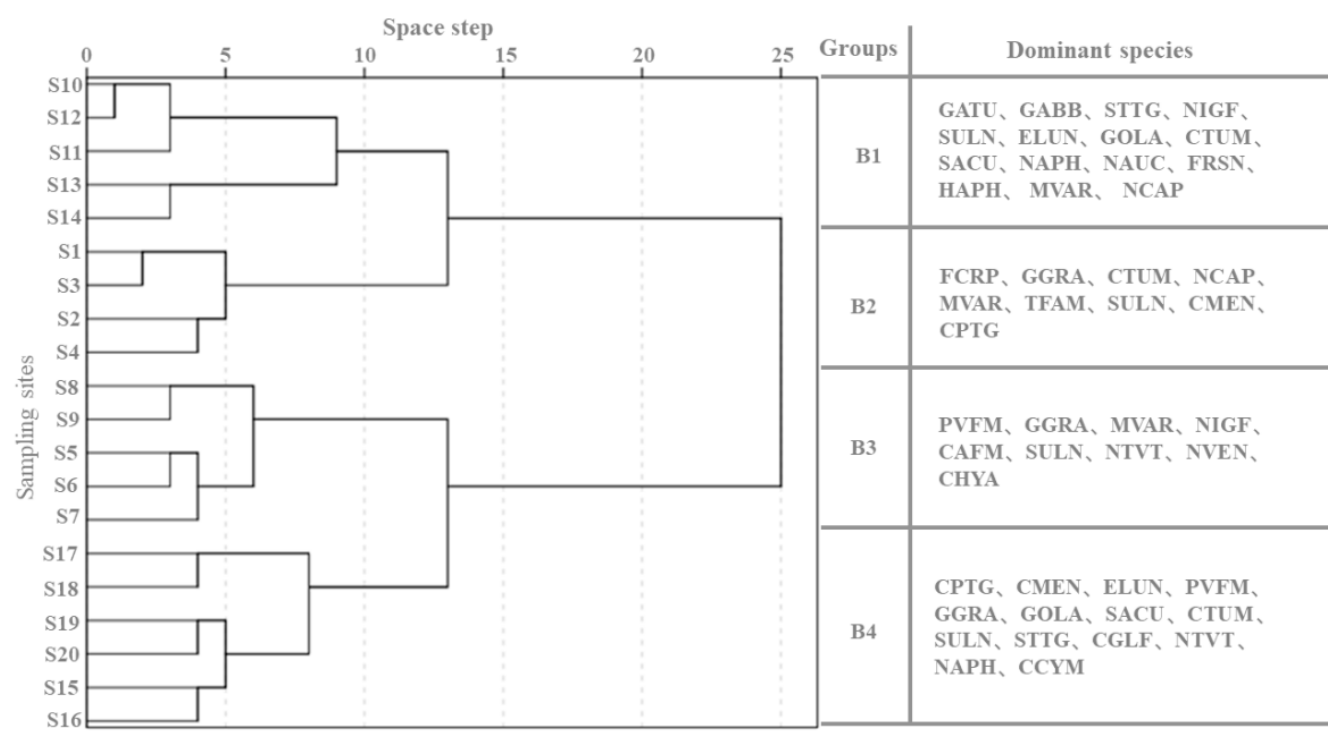

Figure 2. Dendrogram chart for the cluster analysis of the diatom communities.

\subsection{Applicability of Diatom Indices}

Indices of 18 European diatom were calculated, which were presented by numbers ranging from 1 to 20, indicating different grades for ecological health status. As confirmed in public references, the status of the water ecosystem could be divided into five grades, namely healthy (18-20), good (15-17), fair (12-14), poor (9-11) and very poor (1-8). As illustrated in Figure 3, which was calculated using

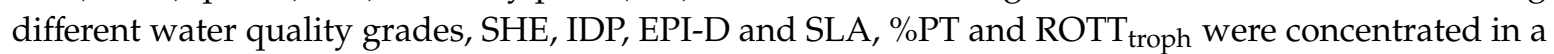
certain range without enough resolution.

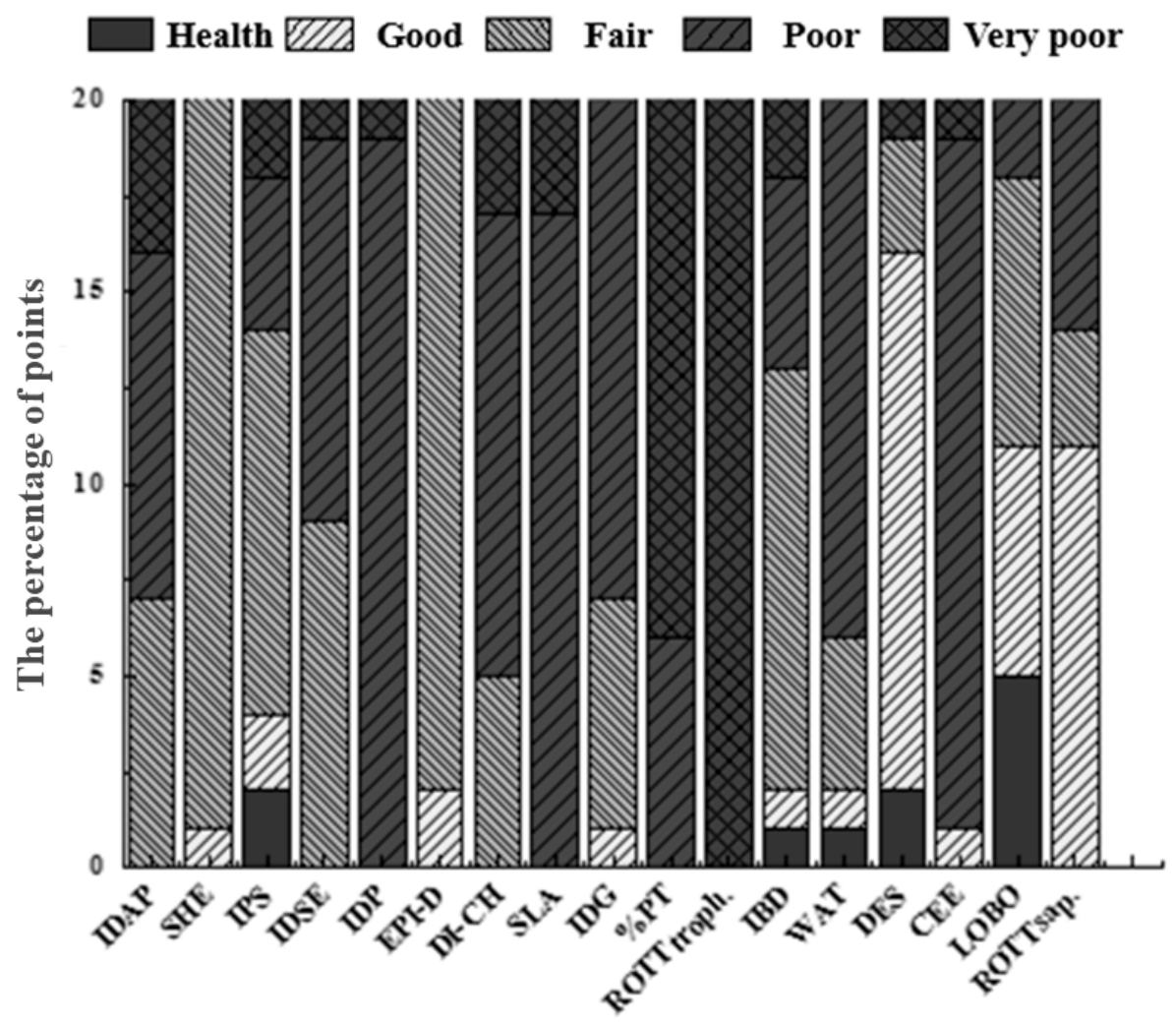

Figure 3. Ecosystem health evaluations for the monitoring sites using 17 diatom indices. 
The remaining 12 diatom indices were then calculated within each group and classified according to water quality A. As presented in Figure 4A-G, 7 diatom indices including LOBO (A), DES (B), CEE (C), TDI (D), IBD (E), IPS (F) and IDSE (G) showed a positive correlation with water quality grade, presenting a decreasing trend from A1 to A4. To further verify the sensitivity of these 7 water quality indices, these 7 diatom indices were recalculated within each group, classified according to water quality B and presented using box plots. As shown in Figure 5, IBD, IPS and IDSE showed a good positive correlation with water quality grade, presenting a consistent trend: B2 > B1 > B3 > B4.

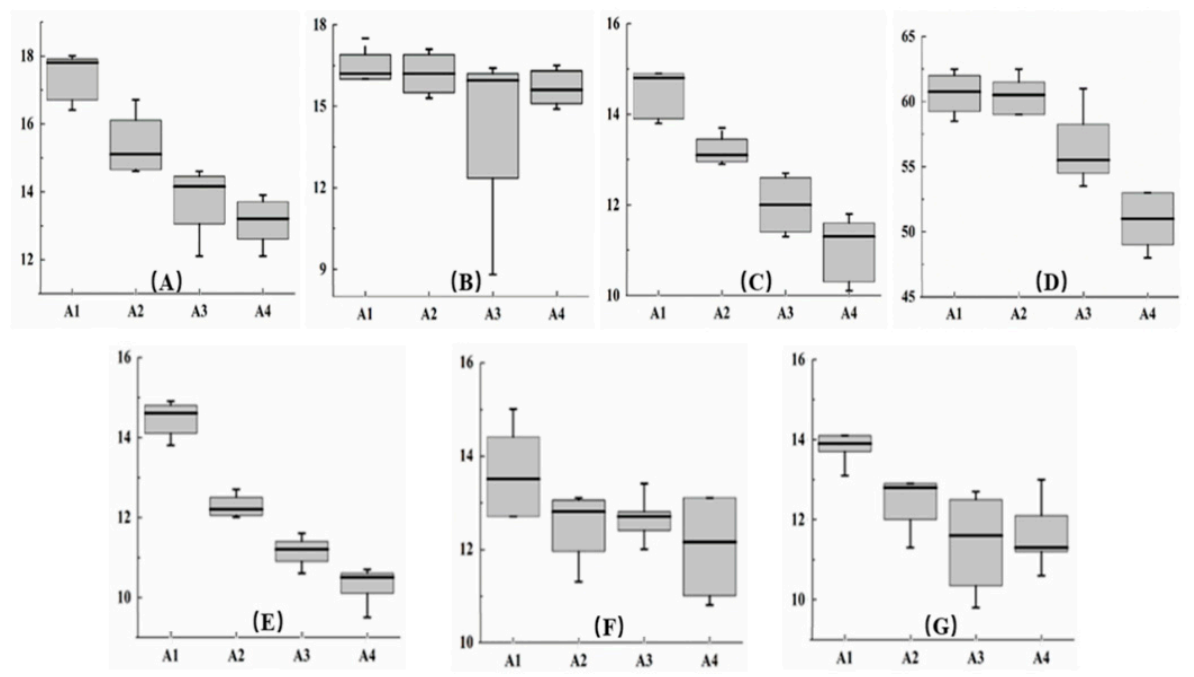

Figure 4. Box plot analysis for 7 metrics in category A (A): Lobo Index (LOBO), (B): Descy Index (DES), (C): European Economic Community Index (CEE), (D): Trophic Diatom Index (TDI), (E): Diatom Biological Index (IBD), (F): Specific Pollution Sensitivity Index (IPS), ((G): Louis Leclercq Diatom Index (IDSE)).

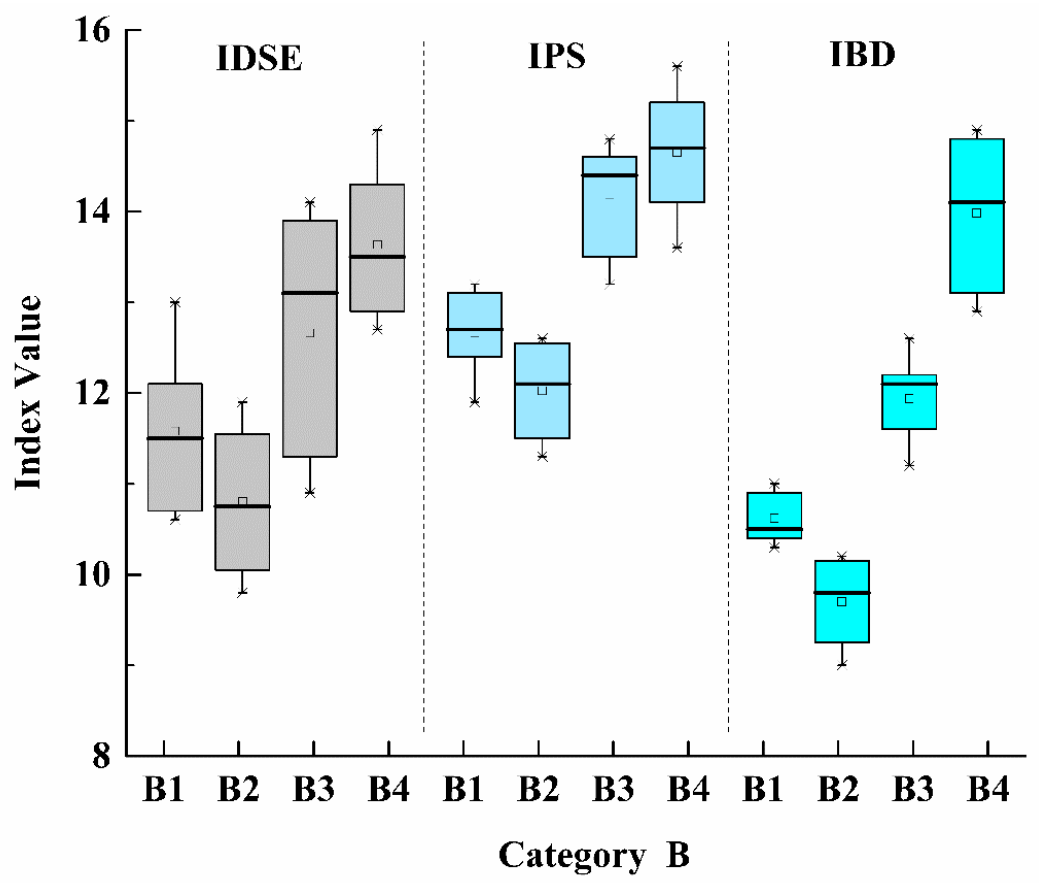

Figure 5. Box plots of IBD, IPS and IDSE calculated within each group classified according to water quality B (note: the pollution levels of the 4 groups have a decreasing trend: B2 > B1 > B3 > B4). 


\section{Discussion}

Since the 1990s, the Nanjishan Nature Reserve had been well protected under the Nature Reserves Administration Regulations [20,43]. However, several dish lakes including Zhan'bei, San'ni and Bai'sha Lake, which are close to an area of human activity, were still used for aquaculture. These lakes were used for harvesting fish from the main lakes during the flooding season of Lake Poyang, by which feeding would bring a large number of nutrients to the dish lake ecosystem and puts these aquatic ecosystems at great risk $[44,45]$. As presented in Table 1, Zhan'bei, San'ni and Bai'sha lakes recorded the highest level for $\mathrm{TN}, \mathrm{TP}, \mathrm{NH}_{4}{ }^{+}, \mathrm{COD}$ and $\mathrm{Chl}$, which has been given high attention in recent years $[4,15]$. Frequent human activities in this area and its proximity to the entrance of Ganjiang River into Lake Poyang also lead to the input and deposition of nutrients [37]. Pearson correlation coefficients revealed that all water quality parameters were highly correlated to each other at a confidence level of 0.05. There was a serious significant correlation among TN, TP, COD, TSS and Chl at a confidence level of 0.01. As presented in Table 1, group A4, including sampling sites S1, S2, S3 and S4 in Lake Zhan'bei, S10, S11 and S12 in Lake San'ni and S13 and S14 in Lake Bai'sha, was observed to have the highest integrated scores. Meanwhile, integrated scores from group A1, including sampling sites S17, S18, S19 and S20 from Lake Shang'bei and Hong'xing, was confirmed to have the lowest values and is far away from human activities and close to the main water area of Poyang Lake.

Because of their sensitive and rapid response to water ecosystem environmental change, diatom communities have been widely used in the world to provide highly informative assessments for ecosystem impairment and biotic integrity of ecosystems [46,47]. Among diatom communities, indicator diatoms such as Melosira varians, Gomphonema gracile and Pinnularia viridis are usually used to indicate eutrophication and organic pollution of water bodies [31,48]. As presented in Figure 2 and Table 2, Synedra acus, Melosira varians and Navicula capitata were confirmed as the dominant species in group B1, classified using clustering analysis and consisting of S10, S11 and S12 in Lake San'ni, and S13 and S14 in Lake Bai'sha. Synedra acus recorded the highest dominance index of 0.043, indicating higher level eutrophication in these areas, which was consistent with the water quality assessment results. As discussed above, the highest values of TN $(0.57 \mathrm{mg} / \mathrm{L}), \mathrm{TP}(0.07 \mathrm{mg} / \mathrm{L}), \mathrm{NH}_{4}^{+}(0.39 \mathrm{mg} / \mathrm{L})$, COD $(28.3 \mathrm{mg} / \mathrm{L})$ and $\mathrm{Chl}(9.35 \mathrm{mg} / \mathrm{L})$ were observed in group A4. Although aquaculture has been prohibited, research has still confirmed high levels of TOM and humus in the surface sediment, which might be one of the factors that lead to eutrophication in these areas [27,34].

Diatom communities of group B2, including sampling sites S1, S2, S3 and S4 in Lake Zhan'bei, were dominated by Melosira varians and Navicula capitata, which are usually used to indicate higher organic materials [22]. Furthermore, they also had high levels of Fragilaria capucina, Cymbella tumida, Synedra ulna, Cyclotella meneghiniana, Cocconeis placentula and so on, which indicated that the water ecosystem in this group received both higher level organic matters and nutrients. Lake Zhan'bei was the first lake used for aquaculture in the 1980s, where higher level TN, TP, TOC, TOM and heavy metal contents were also recorded in the sediments [37]. In group B3, including sampling sites S5, S6 and S7 in Lake Chang and S8 and S9 in lake Nan'shen, the total number and dominance of Gomphonema gracile and Melosira varians were less than the number confirmed in groups B1 and B2, and Caloneis hyaline and Navicula veneta recorded a higher level. The co-existence of these indicator species indicated that Lake Chang and Nan'shen were still partially disturbed by human activities with organic matters input. In addition, these areas are currently located by roads where boat transport is frequently observed. In group B4, clustered by Lake Bei'shen, Shang'bei and Hong'xing, the dominant diatom species were Cymbella cymbiformis, Gomphonema olivaceum and Navicula trivialis, which were indicators of environmental cleanliness as a result of being far from the residential areas [49].

Redundancy Analysis (RDA) is widely used in ecological data analysis, which can decompose the change of species composition into the variation related to environmental variables, so as to explore the relationship between community species composition and environmental variables [11,14]. Many studies have found that RDA can be used for classification and get good results [50,51]. In this study, Detrended Correspondence Analysis (DCA) and the RDA were used in order to further analyze 
diatom communities and determine which species were affected by specific environmental factors. The maximum of the lengths of the gradient in the axes of DCA was 0.19 , which was less than 3. Therefore, a linear model was selected to perform RDA on environmental factors and diatom communities as illustrated in Figure 6. RDA showed a relationship on all axes; the axis 1 accounted for $17.35 \%$ of total variability and axis 2 accounted for $15.28 \%$ of total variability. The cumulative explanatory variable of $\mathrm{TN}, \mathrm{TP}$ and $\mathrm{Chl}$ accounts for $32.63 \%$, more than the cumulative explanatory variable of any three environmental factors. Most of the dominant taxa indicators of eutrophication water quality were closely associated with the vectors of TN, TP and Chl. It was concluded from Figure 6 that TN, TP and Chl were the main environmental driving factors in this area. It was also verified that $\mathrm{TN}, \mathrm{TP}$ and $\mathrm{Chl}$ had a greater impact on water quality classification, which further indicated that the classification was reliable.

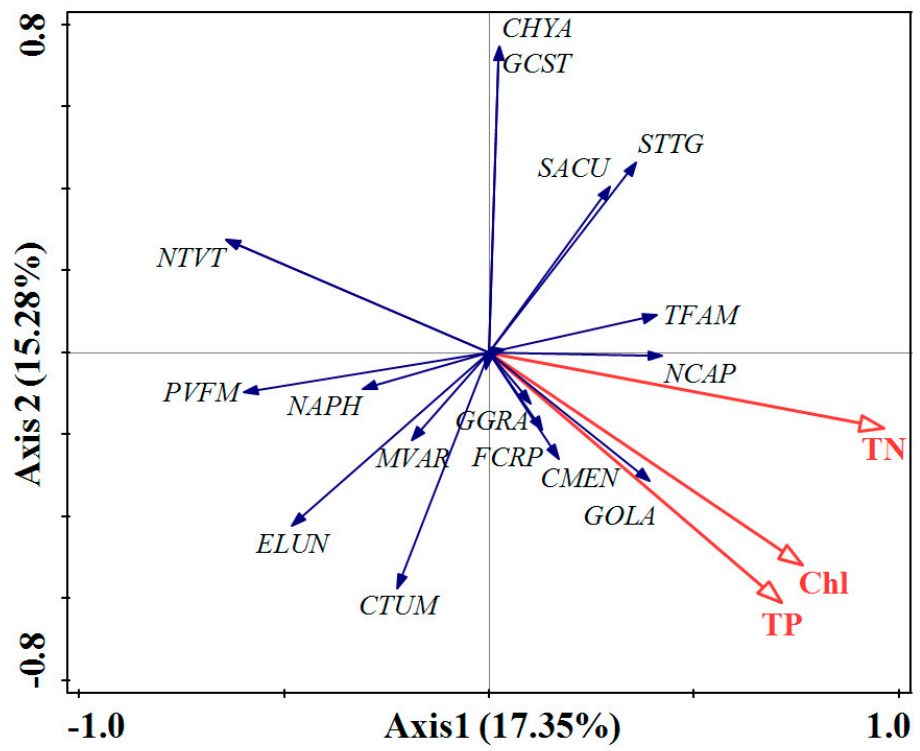

Figure 6. Redundancy Analysis (RDA) showing the main environmental driving factors in this area (note: red lines (main environmental impact factors), blue lines (diatom abbreviation)).

As an effective water quality assessment method, diatom indices are one of the most widely used water quality assessment techniques and have been widely researched in the scientific community [52,53]. However, studies revealed that diatom indices developed in one geographic area or environment were less successful when applied in other areas and may cause uncertain results [31,32]. Aiming to confirm the differentiation or sensitivity of the diatom index, 18 European diatom indices were selected as the appropriate indices for further research and wetland evaluation in the Nanjishan Nature Reserve. Except for TDI, the greater the values of the diatom indices, the better the water ecological status was [4,27]. As illustrated in Figure 3, results for diatom indices calculated for 20 sites in this research indicated that SHE, IDP, EPI-D, SLA, \%PT and ROTT troph could not be used in Nanjishan Reserve for water quality assessment because of less differentiation. Most of the above-mentioned diatom indices (SHE, IDP, EPI-D, SLA, \%PT and ROTT troph) were mainly calculated with the "key taxas" such as Eunotia arcus, Caloneis hyaline, Gomphonema constrictum and Navicula trivialis [22,48], and Eunotia arcus, Caloneis hyaline, Gomphonema constrictum and Navicula trivialis were widely distributed in the 20 sample sites of this study

The application of diatom indices indicated strong correlations with physical and chemical parameters, and lots of studies have linked diatom indices with water quality around the world $[15,52,53]$. For applicability assessment of diatom indices, the analysis of diatom indices and water quality evaluation results was a very important method, which was beneficial to screening diatom indices [28]. In this study, the remaining diatom indicators will be further recalculated at the 
next step according to water quality classification category A. As presented in Figure 4, only seven diatom indices including LOBO, DES, CEE, TDI, IBD, IPS and IDSE showed the same trend of water quality, which also existed in most studies of the applicability of the diatom indices $[4,7,27]$. As shown in Table 3, diatom indices and environmental variables were analyzed using Pearson correlation, where significant correlation at level $p<0.05$ was observed among most of the environmental variables and diatom indices. IBD and IPS significantly correlated with most environmental variables while SHE, DI-CH, SLA, WAT and DES with the least. TSS did not correlate significantly with most index scores. Strong and significant correlations were also observed between most diatom indices. IBD significantly correlated with IPS, and they were significantly correlated with TN, TP and Chl, which had a greater impact on water quality classification.

Diatoms are considered successful bio-monitors worldwide, and different levels of water quality have been known to have a significant effect on diatom community composition thereby affecting index scores [48,54]. As shown in Figure 5, box plot analysis was further executed for LOBO, DES, CEE, TDI, IBD, IPS and IDSE, based on diatom clustering results. Only IBD, IPS and IDSE were consistent with the diatom clustering trend as category B. Deng [7] revealed that the evaluation of diatom indices was highly related to physical and chemical characteristics of the water, as well as geography, hydrology factors and climatic factors. Studies conducted in France indicated that IBD was highly associated with water quality and has been extensively used in different stream water quality monitoring programs [55]. Deng [7] revealed that IPS was closely related to IBD and mentioned that IPS and IBD were suitable indices for water quality assessment in Dongiiang River. IBD, IPS and IDSE indices together could be good indicators for organic pollution, salinity and eutrophication because they reflected a large number of species. In this study, 24 species of diatoms were selected as "key taxa" to IBD, IPS and IDSE, of which Fragilaria capucina, Cymbella tumida, Synedra ulna, Synedra acus, Navicula capitata, Melosira varians and Navicula veneta were the dominant species. The changes of an abundance of these dominant species was consistent with the trend of cluster analysis, which revealed that IBD, IPS and IDSE could be consistent with the diatom clustering trend as category B, and could be suitable diatom indices for the ecological health assessment of the Nanjishan Nature Reserve.

In this study, the method of statistical analysis was used to preliminarily screen the optimal diatom index in the Nanjishan Nature Reserve, which provides basic reference materials and biological data for constructing a diatom index for the biological evaluation of water quality in the Nanjishan Nature Reserve. Most diatom indices have been developed with the intent of monitoring organic pollution and eutrophication and are based on associated variables such as TP, TN and Chl. These variables are commonly used to determine the pollution status and have low levels and narrow range in rivers and streams. In such conditions, maybe other variables such as $\mathrm{pH}$ and temperature are important factors for structuring diatom communities and consequently determining the diatom indices. Probably in the future, further studies should be done when more data are available to conduct relevant experiments which consider more factors to screen applicable diatom indices, and diatom indices could be developed to monitor pristine water bodies with high water quality. 
Table 3. Correlation coefficients between the 18 diatom indices and physiochemical variables.

\begin{tabular}{|c|c|c|c|c|c|c|c|c|c|c|c|c|c|c|c|c|c|}
\hline Items & IDAP & SHE & IPS & IDSE & TDI & IDP & EPI-D & DI-CH & SLA & IDG & $\%$ PT & ROTT $_{\text {troph }}$ & IBD & WAT & DES & CEE & LOBO \\
\hline SHE & -0.104 & & & & & & & & & & & & & & & & \\
\hline IPS & $0.515 *$ & 0.064 & & & & & & & & & & & & & & & \\
\hline IDSE & 0.144 & $0.506^{*}$ & 0.300 & & & & & & & & & & & & & & \\
\hline TDI & 0.282 & 0.185 & $0.664^{* *}$ & $0.479 *$ & & & & & & & & & & & & & \\
\hline IDP & 0.217 & 0.196 & -0.023 & 0.151 & 0.186 & & & & & & & & & & & & \\
\hline EPID & -0.225 & 0.084 & 0.415 & 0.388 & 0.162 & -0.280 & & & & & & & & & & & \\
\hline $\mathrm{DICH}$ & 0.387 & 0.381 & $0.606^{* *}$ & $0.643 * *$ & $0.764 * *$ & $0.461 *$ & 0.169 & & & & & & & & & & \\
\hline SLA & $0.600 * *$ & -0.189 & 0.366 & -0.015 & 0.037 & 0.383 & 0.061 & 0.042 & & & & & & & & & \\
\hline IDG & 0.177 & 0.15338 & 0.305 & 0.373 & 0.329 & -0.373 & 0.098 & $0.432 *$ & $-0.549^{* *}$ & & & & & & & & \\
\hline PT & 0.019 & $-0.447 *$ & -0.400 & $-0.439 *$ & $-0.621 * *$ & -0.085 & -0.040 & $-0.570^{* *}$ & 0.371 & $-0.427^{*}$ & & & & & & & \\
\hline ROTT $_{\text {troph }}$ & $0.674^{* *}$ & 0.081 & $0.547^{\text {***}}$ & $0.605^{* *}$ & $0.458^{*}$ & 0.341 & 0.171 & $0.537^{* *}$ & $0.659^{* *}$ & -0.030 & -0.155 & & & & & & \\
\hline IBD & $0.679^{* *}$ & -0.037 & 0.794 ** & 0.081 & $0.489 *$ & -0.055 & 0.112 & $0.529 *$ & 0.302 & 0.384 & -0.269 & 0.514 * & & & & & \\
\hline WAT & 0.100 & 0.351 & -0.292 & -0.199 & -0.395 & 0.196 & -0.229 & -0.349 & 0.415 & $-0.626^{* *}$ & 0.228 & 0.125 & -0.139 & & & & \\
\hline DES & -0.007 & 0.187 & 0.326 & $0.473 *$ & 0.361 & -0.415 & 0.319 & $0.475^{*}$ & $-0.607^{* *}$ & $0.938^{* *}$ & $-0.467^{*}$ & -0.002157 & 0.356 & $-0.654^{* *}$ & & & \\
\hline CEE & 0.103 & $0.461 *$ & -0.015 & -0.367 & -0.211 & -0.122 & -0.226 & -0.218 & 0.049 & -0.191 & 0.018 & -0.195 & 0.152 & $0.722 * *$ & -0.253 & & \\
\hline LOBO & 0.341 & -0.373 & 0.050 & $-0.784^{* *}$ & -0.340 & -0.054 & -0.340 & -0.348 & 0.242 & -0.155 & $0.456^{*}$ & -0.309 & 0.229 & 0.161 & -0.344 & $0.457^{*}$ & \\
\hline ROTT $_{\text {sap }}$ & 0.355 & 0.234 & $0.591^{* *}$ & 0.820 ** & 0.653 ** & 0.143 & 0.339 & 0.701 ** & 0.223 & $0.789 * *$ & -0.285 & $0.686^{* *}$ & 0.316 & $-0.497 *$ & $0.826^{* *}$ & $-0.433^{*}$ & -0.445 * \\
\hline $\mathrm{TN}$ & -0.409 & 0.081 & $-0.455 *$ & -0.049 & $0.548 *$ & $-0.455 *$ & $-0.475^{*}$ & 0.050 & -0.134 & 0.053 & -0.285 & 0.142 & $0.905 * *$ & 0.232 & 0.152 & 0.205 & $0.450 *$ \\
\hline $\mathrm{TP}$ & $-0.515 *$ & -0.050 & $-0.535 *$ & 0.458 * & 0.206 & -0.028 & -0.018 & 0.112 & -0.157 & $0.626^{*}$ & -0.269 & -0.028 & $0.725^{* *}$ & 0.044 & 0.107 & $0.535 *$ & 0.106 \\
\hline COD & -0.077 & -0.218 & -0.137 & -0.151 & -0.450 * & -0.264 & 0.097 & -0.306 & 0.142 & -0.117 & $0.661^{* *}$ & -0.163 & -0.226 & -0.001 & -0.102 & 0.004 & 0.226 \\
\hline TSS & -0.080 & -0.260 & -0.133 & -0.175 & -0.301 & -0.301 & 0.065 & -0.368 & 0.010 & 0.036 & -0.013 & -0.281 & -0.326 & -0.216 & -0.056 & -0.119 & 0.359 \\
\hline Chl & 0.214 & -0.002 & $0.406^{*}$ & $0.517^{* *}$ & 0.221 & 0.248 & -0.190 & 0.058 & 0.214 & -0.120 & $0.575^{* *}$ & 0.096 & $0.493 *$ & 0.001 & -0.264 & -0.059 & 0.085 \\
\hline $\mathrm{NH}_{4}{ }^{+}$ & -0.030 & -0.153 & -0.206 & 0.345 & 0.095 & 0.276 & 0.161 & 0.002 & 0.285 & -0.285 & 0.060 & 0.293 & -0.381 & 0.043 & -0.285 & $-0.505 *$ & $-0.471 *$ \\
\hline
\end{tabular}

Note1: ${ }^{*}$ - -the correlation is extremely significant when the confidence is $0.01 ; *$-the correlation is significant at a confidence level of 0.05 . 


\section{Conclusions}

A total of 77 species belonging to 34 genera were identified in the dish lake basin of the Nanjishan Nature Reserve, and the dominant species were Melosira varians (adapted to organic pollution), Fragilaria capucina, Synedra ulna, Cyclotella meneghiniana (indicated human-induced disturbance of eutrophication), Cocconeis placentula and Navicula veneta, which showed that the dish lake of Nanjishan Nature Reserve was in moderate pollution state. The main driving factors of the dish lake basin of Nanjishan Nature Reserve were TP, TN and Chl, indicating that the basin was affected by eutrophication due to human disturbances. Among all diatom indices, IBD, IPS and IDSE were the most suitable evaluation diatom indices for the dish lake basin of Nanjishan Nature Reserve.

Author Contributions: J.Y. and Y.J. conceived and designed the research; J.Y. and J.Z. performed the research; J.Y. contributed to data analysis of this work; R.Y. and Y.J. made the pictures and polished the paper; J.Y., R.Y., X.L., N.W., and K.W. All authors have read and agreed to the published version of the manuscript.

Funding: This research was funded by [the National Natural Science Foundation of China] grant number [51769015; 51879128], [Jiangxi Provincial Technology Department] grant number [20171ACB21050; 20182BCB22013], [Jiangxi Provincial Department of Transportation] grant number [2019C0003] and [Graduate Innovation Program of Nanchang Institute of Technology] grant number [YJSCX20190002].

Acknowledgments: Special and sincere thanks to Yue Zhang, Yi Zhang, Yingying Feng and Juan Zhou for their help in the field sampling.

Conflicts of Interest: The authors declare no conflict of interest.

\section{References}

1. Tan, X.; Ma, P.; Bunn, S.E.; Zhang, Q.F. Development of a benthic diatom index of biotic integrity (BD-IBI) for ecosystem health assessment of human dominant subtropical rivers, China. J. Environ. Manag. 2015, 151, 286-294. [CrossRef] [PubMed]

2. Yan, J.W.; Fa, Y.L. The application of benthic macroinvertebrates in aquatic ecosystem health assessment. J. Meteorol. Environ. 2012, 28, 90-96.

3. Friberg, N. Biomonitoring of human impacts on freshwater ecosystems: The good, the bad and the ugly. Adv. Ecol. Res. 2011, 44, 1-68.

4. Li, Z.W.; Cao, R.; Mao, J.Z.; Sheng, X.; Wang, X.T.; Deng, P.Y. Study of proper diatom-based indices for bioassessment of water quality in Beijiang Watershed. Ecol. Environ. Sci. 2017, 26, 275-284. (In Chinese)

5. Almeida, S.F.P.; Elias, C.; Ferreira, J.; Tomes, E.; Puccinelli, C.; Delmas, F.; Doerflinger, G.; Urbanic, G.; Marcheggiani, S.; Rosebery, J. Water quality assessment of rivers using diatom metrics across Mediterranean Europe: A methods intercalibration exercise. Sci. Total Environ. 2014, 476-477, 768-776. [CrossRef]

6. Pignata, C.; Morin, S.; Scharl, A.; Traversi, D.; Schiliò, T.; Degan, R.; Bartley, P.; Tu, M.; Liu, H.; Peres, F. Application of European biomonitoring techniques in China: Are they a useful tool? Ecol. Indic. 2013, 29, 489-500. [CrossRef]

7. Deng, P.Y.; Lei, Y.D.; Liu, W.; Wang, X.T. Exploration of benthic diatom indices to evaluate water quality in rivers in the Dongjiang Basin. Acta Ecol. Sin. 2012, 32, 5014-5024. (In Chinese) [CrossRef]

8. Belore, M.L.; Winter, J.G.; Duthie, H.C. Use of Diatoms and Macroinvertebrates as Bioindicators of Water Quality in Southern Ontario Rivers. Can. Water Resour. J. 2002, 27, 457-484. [CrossRef]

9. Karr, J.R.; Chu, E.W. Introduction: Sustaining living rivers. Hydrobiologia 2000, 422, 1-14. [CrossRef]

10. Schowe, K.; Harding, J. Development of two diatom-based indices: A biotic and a multimetric index for assessing mine impacts in New Zealand streams. N. Z. J. Mar. Freshw. Res. 2014, 48, 163-176. [CrossRef]

11. Wang, Y.K.; Stevenson, R.J.; Metzmeier, L. Development and evaluation of a diatom-based Index of Biotic Integrity for the Interior Plateau Ecoregion, USA. J. N. Am. Benthol. Soc. 2005, 24, 990-1008. [CrossRef]

12. Liu, L.F.; Xu, Z.X.; Yin, X.W.; Wu, W.; Min, W.W. Assessing water quality with diatom indices in the Wei River Basin. J. Beijing Norm. Univ. Nat. Sci. 2016, 52, 317-321. (In Chinese)

13. Xue, H.; Zheng, B.; Meng, F.; Wang, Y.Y.; Cheng, P.X. Assessment of Aquatic Ecosystem Health of the Wutong River Based on Benthic Diatoms. Water 2019, 11, 727. [CrossRef] 
14. Martin, G.; Toja, J.; Sala, S.E.; Fernández, M.D.L.R.; Reyes, I.; Casco, M.A. Application of diatom biotic indices in the Guadalquivir River Basin, a Mediterranean basin. Which one is the most appropriated? Environ. Monit. Assess. 2010, 170, 519-534. [CrossRef]

15. Srivastava, P.; Grover, S.; Verma, J.; Khan, S.A. Applicability and efficacy of diatom indices in water quality evaluation of the Chambal River in Central India. Environ. Sci. Pollut. Res. 2017, 24, 25955-25976. [CrossRef]

16. Dela-Cruz, J.; Pritchard, T.; Gordon, G.; Ajani, P. The use of periphytic diatoms as a means of assessing impacts of point source inorganic nutrient pollution in south-eastern Australia. Freshw. Biol. 2006, 51, 951-972. [CrossRef]

17. Frédéric, R. Recent views on river pollution and diatoms. Hydrobiologia 2012, 683, 1-24.

18. Lavoie, I.; Campeau Stéphane Zugic-Drakulic, N.; Winter, J.G.; Fortin, C. Using diatoms to monitor stream biological integrity in Eastern Canada: An overview of 10 years of index development and ongoing challenges. Sci. Total Environ. 2014, 475, 187-200. [CrossRef]

19. Besse-Lototskaya, A.; Verdonschot, P.F.M.; Coste, M.; Vijver, B.V.D. Evaluation of European diatom trophic indices. Ecol. Indic. 2011, 11, 467. [CrossRef]

20. Grenier, M.; Lavoie, I.; Rousseau, A.N.; Campeau, S. Defining ecological thresholds to determine class boundaries in a bioassessment tool: The case of the Eastern Canadian Diatom Index (IDEC). Ecol. Indic. 2010, 10, 980-989. [CrossRef]

21. Rimet, F.; Bouchez, A.; Montuelle, B. Benthic diatoms and phytoplankton to assess nutrients in a large lake: Complementarity of their use in Lake Geneva (France-Switzer-land). Ecol. Indic. 2015, 53, 231-239. [CrossRef]

22. Dam, H.V.; Mertens, A.; Sinkeldam, J. A coded checklist and ecological indicator values of freshwater diatoms from The Netherlands. Aquat. Ecol. 1994, 28, 117-133. [CrossRef]

23. Atazadeh, I.; Sharifi, M.; Kelly, M.G. Evaluation of the Trophic Diatom Index for assessing water quality in River Gharasou, western Iran. Hydrobiologia 2007, 589, 165-173. [CrossRef]

24. Delgado, C.; Pardo, I.; García, L. A multimetric diatom index to assess the ecological status of coastal Galician rivers (NW Spain). Hydrobiologia 2010, 644, 371-384. [CrossRef]

25. $\mathrm{Wu}, \mathrm{J} . ; \mathrm{Kow}, \mathrm{L}$. Applicability of a generic index for diatom assemblages to monitor pollution in the tropical River Tsanwun, Taiwan. J. Appl. Phycol. 2002, 14, 63-69. [CrossRef]

26. Trábert, Z.; Tihamér Kiss, K.; Várbíró, G.; Dobosy, P.; Grigorszky, I.; Ács, É. Comparison of the utility of a frequently used diatom index (IPS) and the diatom ecological guilds in the ecological status assessment of large rivers. Fundam. Appl. Limnol. Arch. Hydrobiol. 2017, 189, 87-103. [CrossRef]

27. Yin, X.W.; Qu, X.D.; Li, Q.N.; Liu, Y.; Zhang, Y. Using periphyton assemblages to assess stream conditions of Taizi River Basin, China. Acta Ecol. Sin. 2012, 32, 1677-1691. (In Chinese)

28. Kalyoncu, H.; Şerbetci, B. Applicability of Diatom-Based Water Quality Assessment Indices in Dari Stream, Isparta Turkey. World Acad. Sci. Eng. Technol. Int. J. Environ. Chem. Ecol. Geol. Geophys. Eng. 2013, 7, 386-394.

29. Pipp, E. A regional diatom-based trophic state indication system for running water sites in Upper Austria and its overregional applicability. Int. Ver. Theor. Angew. Limnol. Verh. 2001, 27, 3376-3380. [CrossRef]

30. Stevenson, R.J.; Zalack, J.T.; Wolin, J. A multimetric index of lake diatom condition based on surface-sediment assemblages. Freshw. Sci. 2013, 32, 1005-1025. [CrossRef]

31. Taylor, J.C.; Van Vuuren, M.S.; Pieterse, A.J. The application and testing of diatom-based indices in the Vaal and Wilge Rivers, South Africa. Water SA 2009, 33, 51-59. [CrossRef]

32. Zgrundo, A.; Bogaczewiczadamczak, B. Applicability of diatom indices for monitoring water quality in coastal streams in the Gulf of Gdansk Region, Northern Poland. Oceanol. Hydrobiol. Stud. 2004, 33, 31-46.

33. Kelly, M.; Whitton, B.A. The Trophic Diatom Index: A new index for monitoring eutrophication in rivers. J. Appl. Phycol. 1995, 7, 433-444. [CrossRef]

34. Kelly, M.G. Use of the trophic diatom index to monitor eutrophication in rivers. Water Res. 1998, 32, $236-242$. [CrossRef]

35. Zhang, Q.H.; Dong, X.H.; Chen, Y.W.; Yang, X.D.; Xu, M.; Davidson, T.A.; Jeppesen, E. Hydrological alterations as the major driver on environmental change in a floodplain Lake Poyang (China): Evidence from monitoring and sediment records. J. Great Lakes Res. 2018, 44, 377-387. [CrossRef]

36. Liu, X.; Qian, K.M.; Chen, Y.W. Effects of water level fluctuations on phytoplankton in a Changjiang River floodplain lake (Poyang Lake): Implications for dam operations. J. Great Lakes Res. 2015, 41, 770-779. [CrossRef] 
37. Ji, Y.; Zhang, J.; Zhang, L.W.; Li, X.L.; Wu, D.D.; Liu, J.L.; Li, J. Analysis of heavy metals in the surface sediments of shallow lakes in Nanjishan (Poyang Lake) Natural Wetland in China. J. Environ. Biol. 2017, 38, 561-570.

38. Wei, F.S. Water and Wastewater Monitoring and Analysis Methods, 4th ed.; China Environmental Press: Beijing, China, 2002.

39. Kelly, M.; Bennett, C.; Coste, M.; Delgado, C.; Delmas, F.; Denys, L.; Ector, L.; Fauville, C.; Ferréol, M.; Golub, M. A comparison of national approaches to setting ecological status boundaries in phytobenthos assessment for the European Water Framework Directive: Results of an intercalibration exercise. Hydrobiologia 2009, 621, 169-182. [CrossRef]

40. Kelly, M.; Bennion, H.; Burgess, A.; Ellis, J.; Juggins, S.; Guthrie, R. Uncertainty in ecological status assessments of lakes and rivers using diatoms. Hydrobiologia 2009, 633, 5-15. [CrossRef]

41. Lavoie, I.; Campeau, S.; Grenier, M.; Dillon, P.J. A diatom-based index for the biological assessment of eastern Canadian rivers: An application of correspondence analysis (CA). Can. J. Fish. Aquat. Sci. 2006, 63, 1793-1811. [CrossRef]

42. Zelinka, M.; Marvan, P. Zur Przisierung der biologischen Klassifikation des Reinheit fliessender Gewsser. Archiv für. Hydrobiologie 1961, 57, 389-407.

43. Fulazzaky, M.A. Water quality evaluation system to assess the Brantas River water. Water Resour. Manag. 2009, 23, 3019-3033. [CrossRef]

44. Hu, M.; Wu, Z.; Zhou, H.; Zhang, A.F.; Song, W.; Zhang, C.Z. The fisheries characters and resource status of Nanjishan natural reserve in Poyang lake. Resour. Environ. Yangtze Basin 2005, 14, 561-565.

45. Zhang, B.; Song, X.; Zhang, Y.; Han, D.M.; Tang, C.Y.; Yu, Y.L.; Ma, Y. Hydrochemical characteristics and water quality assessment of surface water and groundwater in Songnen plain, Northeast China. Water Res. 2012, 46, 2737-2748. [CrossRef] [PubMed]

46. Mannion, A.M. The diatoms: Applications for the environmental and earth sciences. J. Biol. Educ. 2012, 46, 200-201. [CrossRef]

47. Stancheva RSheath, R.G. The diatoms: Applications for the environmental and earth sciences. J. Phycol. 2012, 48, 261-262. [CrossRef]

48. Tokatli, C.; Solak, C.N.; Yilmaz, E. Water Quality Assessment by Means of Bio-Indication: A Case Study of Ergene River Using Biological Diatom Index. Aquat. Sci. Eng. 2020, 36, 43-51. [CrossRef]

49. Ji, Y.; Wang, X.R.; Zhu, W.B.; Wu, P.J.; Gao, G.Q. Effects of substrate types on the growth of typical submerged vegetation in Poyang Lake. J. Nanchang Inst. Technol. 2018, 37, 38-42.

50. Bere, T.; Mangadze, T.; Mwedzi, T. The application and testing of diatom-based indices of stream water quality in Chinhoyi Town, Zimbabwe. Water SA 2014, 40, 503-512. [CrossRef]

51. Tan, X.; Ma, P.; Xia, X.; Zhang, Q.F. Spatial Pattern of Benthic Diatoms and Water Quality Assessment Using Diatom Indices in a Subtropical River, China. Clean Soil Air Water 2014, 42, 20-28. [CrossRef]

52. Lobo, M.T.M.P.S.; Scalize, P.S.; Kraus, C.N.; da Silva, W.J.; Garnier, J.; da Motta Marques, D.; de Souza Nogueira, I. Biological index based on epiphytic diatom assemblages is more restrictive than the physicochemical index in water assessment on an Amazon floodplain, Brazil. Environ. Sci. Pollut. Res. 2020, 27, 1-16. [CrossRef] [PubMed]

53. Torrisi, M.; Dell'Uomo, A. Biological monitoring of some Apennine rivers (central Italy) using the diatom-based eutrophication/pollution index (EPI-D) compared to other European diatom indices. Diatom Res. 2006, 21, 159-174. [CrossRef]

54. Dell'Uomo, A.; Torrisi, M. The Eutrophication/Pollution Index-Diatom based (EPI-D) and three new related indices for monitoring rivers: The case study of the river Potenza (the Marches, Italy). Plant. Biosyst. Int. J. Deal. Asp. Plant. Biol. 2011, 145, 331-341. [CrossRef]

55. Prygiel, J.; Carpentier, P.; Almeida, S.; Coste, M.; Druart, J.; Ector, L.; Guillard, D.; Honore, M.; Iserentant, R.; Ledeganck, P.; et al. Determination of the biological diatom index (IBD NF T 90-354): Results of an intercomparison exercise. J. Appl. Phycol. 2002, 14, 27-39. [CrossRef]

(C) 2020 by the authors. Licensee MDPI, Basel, Switzerland. This article is an open access article distributed under the terms and conditions of the Creative Commons Attribution (CC BY) license (http://creativecommons.org/licenses/by/4.0/). 